\title{
Akupunktur kan være gunstig ved assistert befruktning
}

Forfatterne stilte følgende spørsmål: Hva er effekten av akupunktur gitt i forbindelse med assistert befruktning?

Akupunktur kan bedre fertilitetsraten ved in vitro fertilitsering (IVF). Når akupunktur gis den dagen befruktet egg implanteres slår det positivt ut på raten av levende fødte barn (OR 1,89, 95 prosent KI 1,29 til 2,77). Effekten er ikke til stede når akupunktur gis to til tre dager etter implantasjonen (OR 1,79, 95 prosent KI 0,93 til 3,44). Det er ingen dokumentasjon for at akupunktur har effekt når det gis i tiden egg hentes ut.

Ett av sju til ti par i høyinntekstland kan være subfertile. Mange søker hjelp i helsevesenet for assistert befruktning og de tilbys blant annet stimulering av ovarier, intrauterin inseminasjon og IVF. Akupunktur er gjerne et tilbud innen smertebehandling. Men blir også brukt innen reproduktiv helse, selv om det nødvendigvis ikke er en del av det offentlige helsetilbudet.

Antakelsen om at akupunktur er ufarlig kan bidra til at pasienter og klinikere søker og tilbyr akupunktur som tilleggsterapi i forbindelse med IVF. Basert på studiene $\mathrm{i}$ denne systematiske oversikten bør akupunktur kun tilbys når befruktet egg implanteres. Det bør ikke oppmuntres til akupunktur i lute-

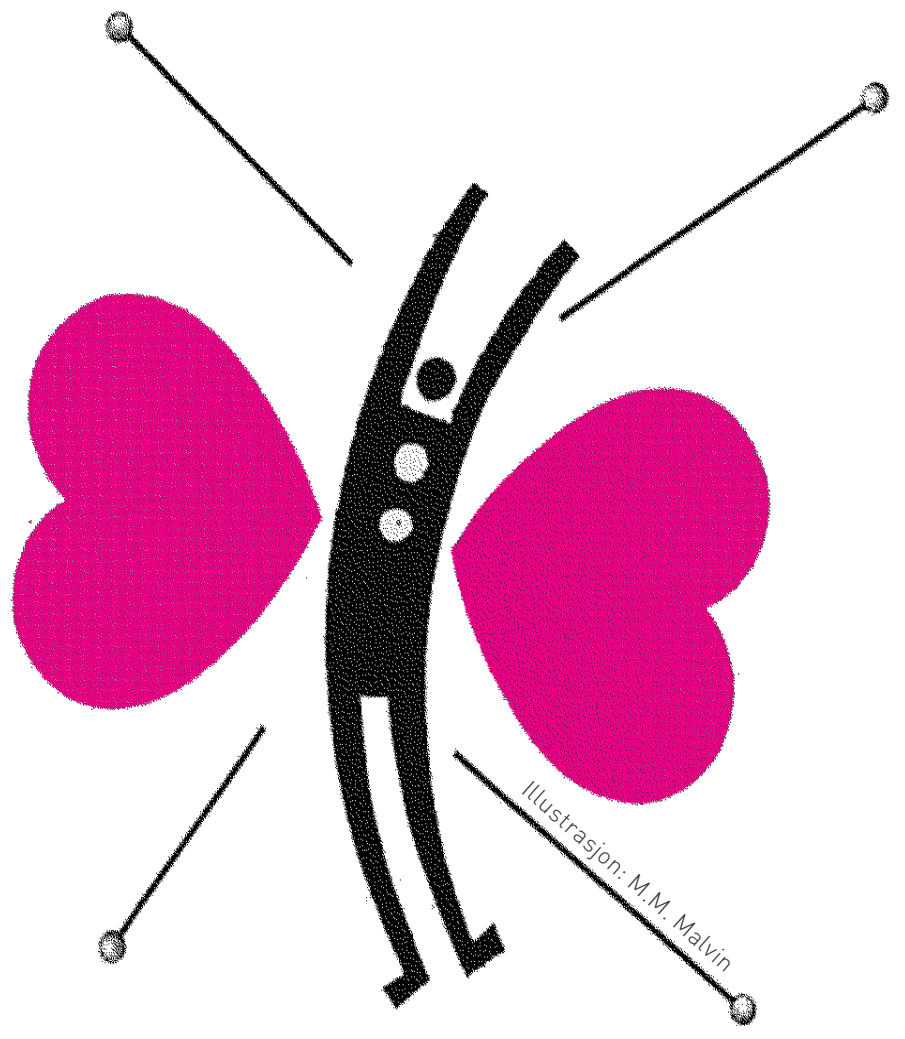

alfasen, før vi har mer kunnskap fra randomiserte studier som har undersøkt en mulig assosiasjon mellom akupunktur i lutealfasen og spontanaborter.

Resultatene baserer seg på 13 studier med vel 2300 pasienter. Forfatterne søkte etter studier fram til august 2007.

\section{Kilde}

Cheong YC et al. Acupuncture and assisted conception. Cochrane Database of Systematic Reviews 2008, Issue 4. Art. No.: CD006920. DOI: 10.1002/14651858. CD006920.pub2.

Skrevet av Liv Merete Reinar, Nasjonalt kunnskapssenter for helsetjenesten 